\title{
Stylizacja językowa w instrukcjach do polskich gier planszowych
}

Language stylisation in the instructions for Polish board games

\section{Iwona Pałucka-Czerniak}

Uniwersytet Zielonogórski

i.palucka-czerniak@ifp.uz.zgora.pl | ORCID: 0000-0002-6037-7729

\begin{abstract}
The article discusses the phenomenon of styling in the genre of instructions, in its sub-form of instructions for a board game. It is recognised that the text of the instructions leads to linguistic creation, introducing the player to the game's specific world. This involves further creation of meanings in the game process and inclusion of users in a culture-based interactive character system. Stylisation occurs in about $20 \%$ of contemporary Polish texts studied. The choice of a less typical strategy for explaining the game's story introduces an element of surprise to the product, provides additional aesthetic impressions, and sometimes even organises the entire game world. Quantitatively, fragments subjected to language stylisation do not prevail. Such stylisation, however, appears in the text frame and concerns not only the lexical layer, but also the language variation, genre, and even discourse.
\end{abstract}

Keywords: stylization, instruction, genre, pragmalinguistics 



\section{Wprowadzenie. Instrukcja do gry planszowej jako zachowanie komunikacyjne}

Gatunek instrukcji, w jego pododmianie instrukcji do gry planszowej, jest szczególnym typem tekstu, ponieważ w tekście instrukcji dochodzi do kreacji językowej, wprowadzającej gracza w swoisty świat gry. Umożliwia ona dalsze tworzenie znaczeń w procesie rozgrywki, włącza użytkowników w interaktywny system znaków, oparty na kulturze (Mochocka, 2015). Jednym z narzędzi tekstotwórczych jest stylizacja językowa, która pozwala nadawcy na obrazowanie nowej rzeczywistości, uobecnianej w czasie gry. W omawianym zachowaniu komunikacyjnym element językowy współgra z elementem ikonicznym: opisowi językowemu towarzyszą kody znakowe wytworzone na potrzeby danej gry oraz ilustracje. Obraz w instrukcji pełni bowiem różnorodne funkcje, przynajmniej informacyjną, artystyczną i kreacyjną. Choć znaczenie elementu ikonicznego jest tu zwykle bardzo duże, niniejsze badanie z racji obszerności zagadnienia skupia się jedynie na aspekcie językowym. Wspomniane kody językowe i ikoniczne odwołują do wiedzy adresata głównie przez wykorzystanie wzoru zachowania językowego zwanego instrukcją do gry planszowej, komunikatu standardowego, choć przyjętego na zasadzie zwyczaju, a nie unormowanego opisanymi i skodyfikowanymi regułami. Wydaje się, że współczesna polska instrukcja do gry planszowej w dużej mierze jest stereotypowa, ma charakter ponadnarodowy, a jej kształt jest zakorzeniony w kulturowym wyobrażeniu zjawisk. Wyrażone bezpośrednio w tekście zasady gry są powiązane z niewyrażonym słownie, umownie przyjętym rozumieniem performatywnego znaczenia tekstu instrukcji dla całości rozgrywki.

\subsection{Specyfika instrukcji jako gatunku użytkowego}

Gatunek instrukcji, w tym w odmianie instrukcji użytkowej dla produktów materialnych, zarówno w perspektywie synchronicznej, jak i diachronicznej, bywał już przedmiotem opisu (Szuk-Bernaciak, 2010; Szczaus, 2011; Troszczyńska-Nakonieczna, 2007, 2008). Instrukcja do gry planszowej, zawierająca główne informacje o produkcie oraz zbiór zasad rządzących rozgrywką, stanowi jednak szczególną realizację gatunku. Omawia bowiem działanie w świecie realnym i wirtualnym równocześnie, 
wskazuje na mechanizmy działań fizycznych, aktualizowanych w czasie rozgrywki, jak i na przebieg wydarzeń w świecie innym, drugim, równoległym do realnego. Instrukcja przedstawia ów fikcyjny świat jako zestaw wyobrażeń na temat miejsca, czasu, uczestników, kontekstu wydarzeń, aspirujący do bycia kompletnym lub otwierający przestrzeń na dopowiedzenia aktorów rozgrywki. Bywa jednak i tak, że bardziej szczegółowe informacje o świecie gry odbiorca uzyskuje dzięki analizie plansz, kart czy dodatków do gry, a w instrukcji przekazywane są główne idee dotyczące mechaniki, przede wszystkim zasad działania opartych na zasadach konstytutywnych (algorytmach gry). Ponadto gdy gra planszowa powstaje jako adaptacja innego tekstu kultury, po pewnym czasie jego istnienia lub równolegle z nim, może być rozumiana albo jako tekst nabierający znaczenia w odniesieniu do wcześniejszego znaku, niekiedy jego paratekst, albo jako element transmedialnej narracji (narratologii: Mochocka, 2015, s. 46).

\subsection{Stylizacja}

Stylizacja jako zabieg językowy, tekstotwórczy, dyskursywny bywa definiowana różnorodnie. Bardzo szeroka definicja tego zjawiska wskazuje, że jest nim sposób kształtowania wypowiedzi; zawężona, stosowana zarówno przez językoznawców, jak i literaturoznawców, wskazuje na celowe i świadome wzorowanie się autora na stylu innego tekstu lub tworzenie własnej wypowiedzi w oparciu o inne, nieautorskie wymogi stylistyczne, właściwe dla innych autorów, zbiorowości osób (szkół, środowisk, epok) lub grup tekstów (stylów funkcjonalnych, prądów, gatunków). (Zdunkiewicz-Jedynak, 2008, s. 97-98; Balbus, 1996; Dubisz, 1980). W szerokim znaczeniu można uznać, że do stylizacji w tekście konkretnej instrukcji dochodzi wówczas, gdy autor kształtuje tekst np. zgodnie ze wzorem funkcjonalnym, stylistycznym i gatunkowym instrukcji do gry planszowej. Analiza tego procesu wymagałaby wskazania specyfiki danego tekstu na tle podstawowych (kanonicznych) i fakultatywnych wyznaczników tego typu tekstu oraz określenia, na ile indywidualna realizacja tekstowa wyzyskuje skonwencjonalizowane wzorce. Jednakże podgatunek instrukcji do gry planszowej jest jeszcze słabo rozpoznany, brakuje zatem punktu odniesienia dla obserwacji zindywidualizowanych czy typowych wyborów językowych twórcy. Punktem odniesienia pozostają tylko ogólne informacje o gatunku instrukcji: 
[...] instrukcja obsługi zaliczana do gatunków praktycznonaukowej sfery komunikacyjnej (technicznej) [Gajda 1993: 180] odgrywa w dyskursie praktycznym istotną rolę w przekazywaniu praktycznej kompetencji w obchodzeniu się / w postępowaniu z produktami technicznymi w relacjach ich producentów z ich nabywcami/użytkownikami. Dyskurs praktyczny pośredniczy między nauką i techniką a adresatem w roli potencjalnego użytkownika o różnorodnym stopniu nabytej wiedzy technicznej (Troszyńska-Nakonieczna, 2013, s. 176).

Nadawca, rozumiany jako producent lub dystrybutor, w zaistniałym układzie komunikacyjnym występuje w pozycji nadrzędnej. Przekazuje $\mathrm{w}$ instrukcji wszystkie istotne informacje dotyczące produktu oraz określa warunki jego poprawnego funkcjonowania. W sformalizowany sposób, uwarunkowany relacją prawną i handlową, określa prawa i obowiązki własne i konsumenta oraz wskazuje konsekwencje wynikające z niewłaściwego użytkowania. Bez wątpienia można stwierdzić, że instrukcja gry planszowej w pewnym stopniu posiada wskazane przez uczoną właściwości. Uwagę zwraca zwłaszcza szczególna pozycja nadawcy, dążenie do precyzji w wyrażaniu treści, hierarchiczny układ elementów, pełnienie przez komunikat funkcji informacyjnej i performatywnej. Jednocześnie wyznaczniki pragmatycznojęzykowe tzw. dyskursu praktycznego lub poradnikowego (Żarski, 2008) zderzają się z dążeniem do sprzedaży gry jako produktu będącego podstawą wydarzenia ludycznego, produktu pozwalającego realizować specyficzne funkcje społeczne, produktu o dużym stopniu oryginalności, interakcyjności i niekiedy artyzmu.

\subsection{Stan badań}

Choć w literaturze przedmiotu znajduje się wiele opracowań przedstawiających walory dydaktyczne gier i zabaw, w tym gier planszowych (Kasprzak, 2018; Kurowska, 2018), a mniej licznie występują także opisy ogólnej specyfiki współczesnych gier planszowych (Mochocka, 2015; Wrona, 2017), to zjawisko instrukcji do gry planszowej jako gatunku tekstu wydaje się jeszcze niewystarczająco zbadane i opisane (Zielińska, 2017, 2018; Łączyński, 2012). Wspomniane analizy zawierają także zróżnicowane treści. Marcin Łączyński mówi o

bogactwie materiału porównawczego, z którego można czerpać wiedzę o różnych rozwiązaniach pisarskich, graficznych i projektowych używanych przy tworzeniu instrukcji. Nie istnieje jeden przyjęty wzór, według którego powstawałyby instrukcje, aczkolwiek pewne kategorie informacji (takie jak opis celów, przebiegu rozgrywki, 
przygotowania do niej czy działania elementów) powtarzają się w nich bardzo często

i są kluczowe dla zrozumienia przebiegu gry przez jej uczestników (2012, s. 131).

W znaczeniu węższym niż realizacja wzorca gatunkowego stylizacji podlegałyby te fragmenty instrukcji, w których autor rezygnuje z oficjalnego, zwięzłego, skondensowanego opisu produktu na rzecz zindywidualizowanego sposobu kreowania świata, wzorowanego na tekstach odmiennych od standardowej instrukcji użytkowej. W tym przypadku analiza tekstów skupiałaby uwagę na językowym kreowaniu „kontekstu”, „fabuły” gry, czyli słownym budowaniu wyobrażenia o świecie.

\subsection{Materiał źródłowy. Kryteria doboru}

Przedmiotem analizy stała się współczesna instrukcja do gry planszowej i karcianej (najczęściej hybrydy), tekst użytkowy (Wojtak, 2008), który dołączany jest do różnorodnych gier i stanowi paratekst w stosunku do samej gry (Loewe, 2007), pełniący funkcję informacyjną, perswazyjną, ludyczną oraz performatywną (kreacyjną: Marcjanik, 1988). Bezpośrednim celem badania jest analiza wyborów językowych, które pozwalają twórcy na powiązanie tematu gry i mechaniki oraz wprowadzenie swoistego klimatu i świata przedstawionego gry. Prezentowane refleksje wynikają z analizy materiału źródłowego: 84 instrukcji do gier planszowych, przeznaczonych dla starszej młodzieży lub osób dorosłych, z lat 2000-2019, z nielicznymi reprezentacjami starszymi lub poszerzającymi krąg odbiorców o młodszych użytkowników. Kryterium doboru nie były jednak typy gier, np. podzielone ze względu na koncentrowanie przekazu na samej mechanice (tzw. eurogry) lub bogactwo fabularne (Wrona, 2017, s. 162). Mechanizm doboru warunkowały dwa czynniki: po pierwsze polskie autorstwo projektu gry, czynnik wynikający z założenia, że autor ma duży wpływ na jakość tekstu, nawet gdy nie jest twórcą samej instrukcji, a po drugie dostępność tekstu. Instrukcje zostały zgromadzone przede wszystkim dzięki zamieszczeniu ich przez wydawców lub portal (wydawcy bądź branżowy) w internecie. $Z$ racji rozproszenia materiału autorka nie dążyła do odnalezienia i wykorzystania wszystkich dostępnych instrukcji gier planszowych polskich autorów. W rezultacie zebrane teksty przybliżają zasady zwykle rozbudowanych gier, wymagających logicznego myślenia, koncentracji i planowania, z kilkoma wyjątkami (gier dla młodszego odbiorcy lub karcianych). 
Kryterium rodzimego autorstwa projektu gry wiąże się z wyłaniającą się z instrukcji językową kreacją świata i fabuły, wpływającą na atrakcyjność i ludyczność produktu. Dlatego charakterystyczne dla tego gatunku jest napięcie między kondensowaniem treści, upraszczaniem przekazu, precyzją wysłowienia a autorskim kreowaniem świata, które wymaga opisu, objaśnienia, narracji.

W konkretnych realizacjach gatunku poddanych analizie mamy do czynienia głównie $\mathrm{z}$ tekstem pisanym prymarnie po polsku, ale uwzględniającym możliwość przekładu na języki obce (z wyjątkiem Nemesis, 2019, w którym instrukcja była tłumaczona na język polski). Jednakże nie można zapominać, że niektóre z gier są tłumaczone na inne języki, a ich dystrybucja odbywa się nie tylko na polskim rynku. Pragmatycznym uwarunkowaniem jest zatem dążenie do jasności i precyzji przekazu. Nie należy więc się spodziewać takich przekształceń językowych, które wykluczą możliwość przekładu. Dotyczy to szczególnie wykorzystania w grze stylizacji artystycznych i manierystycznych.

\subsection{Instrukcja jako gatunek złożony}

Autor gry nie zawsze jest autorem instrukcji, ostateczny kształt produktu powstaje w zespole. Stopka redakcyjna czy wydawnicza w rozmaitym zakresie informuje o podziale obowiązków w składzie grupy, wymieniani są w nich zwykle twórcy gry (koncepcji, mechaniki), ilustratorzy, wydawca, niekiedy testerzy. Choć zatem instrukcja pełni funkcję przewodnika po świecie gry, wprowadzenia z elementami przedmowy do dzieła, jej specyfika wynika ze złożonej sytuacji komunikacyjnej. Instrukcja jawi się jako paratekst, na którym spoczywa ciężar leksykalnego opisu kreowanego świata. W tekście głównym, czyli na planszach do gry, planszetkach, kartach, mogą pojawiać się dodatkowe informacje (np. nazwy przygód, budynków, imiona bohaterów) lub zachodzić zabawy słowem, ale w wielu przypadkach to właśnie w instrukcji zawiera się komplet informacji o stworzonym świecie, co prowadzi do poszerzania jej o gatunki współistniejące: glosariusz (Uździcka, 2017), leksykon tematyczny, FAQ - zestaw pytań i odpowiedzi, artykuł popularnonaukowy, a niekiedy także reklamę. Rozmaite funkcje tekstu wpływają na zaistnienie skali paradoksów: oficjalności - nieoficjalności, obiektywności - emocjonalności, precyzyjności - niedopowiedzenia. Wszystkie 
opisane właściwości odzwierciedlają się w języku tego typu komunikatu, a jedną z nich jest występowanie słownictwa predestynowanego gatunkowo (Borawski, 2007) oraz uporządkowanej struktury (kompozycji: Łączyński, 2017). Językowy obraz świata, który wyłania się z instrukcji, wpływa na atrakcyjność i ludyczność produktu. Charakterystyczne dla tego gatunku jest napięcie między kondensowaniem treści, upraszczaniem przekazu i autorskim kreowaniem świata, które wymaga opisu, objaśnienia, narracji.

\section{Stylizacja w badanym materiale}

\subsection{Miejsce występowania stylizacji. Rama tekstowa}

Stylizacji poddawane są przede wszystkim fragmenty tekstu o szczególnym znaczeniu, występujące w ramie modalnej gatunku - zwłaszcza wprowadzające do gry, które pojawiają się zwykle tuż po tytule. Zanim jednak zostaną przytoczone przykłady takich zabiegów stylistycznych, wypada wskazać standardowy sposób rozpoczynania tekstu instrukcji. W badanym materiale ponad 85\% tekstów zawierało segment, który można skrótowo określić jako wprowadzenie, w części przypadków nieoznaczony żadnym sygnałem metatekstowym, ale wyróżniony graficznie, w części zaś oznaczony tytułem: wstęp, wprowadzenie, słowo wstępu, od autora. W kilkunastu instrukcjach zamiast wprowadzenia lub wraz z nim pojawiały się: list przewodni, list otwarty, dedykacje i podziękowania, fragmenty przemówienia, opis przebiegu gry, a nawet podsumowanie. W przeważającej części materiału źródłowego funkcję wstępu pełniły skrócone opisy fabuły, wyrażone współczesną polszczyzną, jak w przykładzie (cytaty tu i dalej są podawane w wersji oryginalnej):

\footnotetext{
Neuroshima HEx to gra taktyczna, której tematem są bitwy pomiędzy armiami. Akcja gry osadzona jest w świecie wymyślonym na potrzeby gry fabularnej Neuroshima RPG, wydanej przez Wydawnictwo Portal w roku 2001. Znajomość gry Neuroshima RPG nie jest wymagana do gry w HEx, choć gracze, którzy dobrze znają to uniwersum, na pewno lepiej będą znali charakterystyczne cechy i zachowania każdej z czterech armii.
}

Neuroshima RPG to gra, której akcja ma miejsce w postapokaliptycznym świecie, zniszczonym 30-letnią wojną ludzi z maszynami. Resztki ludzkości schroniły się w szczątkach miast i zorganizowały w niewielkie społeczności, organizacje, gangi i armie. [...] Jednak 
większość z rozsianych społeczności ludzi, z HEGEMONIĄ na czele, skupiona jest tylko na własnym przeżyciu i nie interesuje się wojną, dopóki ta nie zawita na ich ziemie (05) ${ }^{1}$.

Charakterystyczne dla tych wstępów okazuje się opisywanie produktu w sposób skoncentrowany na przedmiocie opisu. Nadawcy unikają form pierwszej i drugiej osoby, zdarza się, że wybierają stronę bierną lub opisują działania w czasie przyszłym. Zwykle równocześnie wskazują na cel rozgrywki lub jej specyfikę. Dlatego trudno niekiedy rozgraniczyć autorom pojęcia opisu i celu gry. Odrębność tego typu tekstu jest podkreślana również graficznie - oddzieleniem od innych passusów czy kursywą.

\subsection{Stylizacja na gatunek}

Poza wskazanym typem zabiegów tekstotwórczych w badanym materiale znalazły się wstępy stylizowane na wiadomości prasowe, ogłoszenia, opowiadanie lub baśń, zapis kronikarski, tekst naukowy lub urzędowy. Zdarza się zwłaszcza stylizacja na gatunek epicki, np. opowieść lub gawędę, szczególnie w instrukcjach wzorowanych na konkretnym dziele należącym do epiki. Przykładem tego zjawiska jest pierwszy element narracyjny w instrukcji do gry Stworze (2017):

Zacznę tę opowieść, tak jak mi ją matula opowiadali...

Było to dawno, bardzo dawno temu. Więcej niż sto lat, więcej niż tysiąc. Za wzgórzem, za lasem, kędy kręta rzeka rozlewała się w jeziora. Gdzie puszcza gęsta po horyzont się rozciągała. Między łączkami ślicznymi a szarynnikami podstępnymi, w człowieczej krainie wiara w bogów i ich stworza zaczęła upadać. Oddalali się od wiary chłopy, kobiety i dziatowina. Żercy tracili posłuch. Na próżno przychodziły boginki i demony swoją darowiznę odbierać. Na próżno do chat zaglądały, na skraju pól wyczekiwały. Przestali dbać ludkowie o ich łaskę, zapomnieli ich gniewu. Zapomnieli kto się Krainą opiekuje. Zdecydowały tedy stworzA, że czas się o swoje upomnieć. Opuściły leża i ruszyły między ludzi. Droga do panowania nad Krainą nie była prosta, potrzebne były ofiary. Czego po dobroci osiągnąć nie mogły, to strachem zdobywały. Raz weselem raz tryzną. Długo nie trza było czekać, aż zaczęły sobie w paradę wchodzić. Taka już ich natura, że nie lubiły dzielić się władzą, tedy między sobą konkurować zaczęły, które $\mathrm{z}$ nich jedynym Panem Krainy zostanie.

Resztę tej bajędy poznacie, kiedy w skórę sTworzy wejdziecie... (05)

Autor wykorzystuje mało już znane wyrazy, dawne lub regionalne, np. określenia bagien (szarynnik) czy uczt pogrzebowych powiązanych

1 Oznaczenia na końcu cytatów odwołują do numerów gry z listy zamieszczonej na końcu artykułu. 
z igrzyskami i zapasami (tryzna), pogańskiego kapłana, ofiarnika (żerca), niepoważnego opowiadania, bzdury, gadania (bajęda), sięga po nieużywane już spójniki (kędy, tedy), lub leksemy znane raczej lokalnie bądź w mówionej odmianie języka (dziatowina, trza) oraz neologizm stworza, których w większości przypadków nie notują Słownik języka polskiego Witolda Doroszewskiego (1996, pierwotne wydanie w latach 1958-1969) czy Wielki stownik języka polskiego Piotra Żmigrodzkiego (2007-). Ponadto używa dawnej formy liczby mnogiej chłopy, zdrobnienia ludkowie lub konstrukcji gramatycznych matula opowiadali, zapomnieć gniewu. Jest to próba stylizacji na gawędę, prowadzoną w narracji pierwszoosobowej (zacznęjak mi matula opowiadali), z wyrazistym początkiem baśni (dawno temu), z dwójkowymi i trójkowymi układami składniowymi o paralelnej budowie. Interpunkcja oddaje nie tyle konstrukcję zdania, co system pauz w wypowiedzi. Słownictwo wskazane powyżej częściowo nie jest notowane w słownikach, częściowo zaś datowane jest na wieki od XIV do początków xIx. Po chwili styl narracji zmienia się jednak, autor używa języka współczesnego, ale zachowana zostaje forma bezpośredniego zwrotu do odbiorcy w drugiej osobie liczby mnogiej, zainicjowana już we wcześniejszej narracji:

\footnotetext{
W grze stworze Staniecie się Stworzami - postaciami ze słowiańskiej mitologii, znanymi z bajęd i klechd, przekazywanych z pokolenia na pokolenie. Wasze działania, obecność, wzbudzać będzie wśród ludzi Strach lub Przychylność. To wy wybierzecie drogę, która doprowadzi was do miana jedynego Opiekuna Krainy. (05)
}

Jak widać, wprowadzenie elementów stylizacji na gawędę motywowane jest tematyką gry: nawiązaniem do wierzeń słowiańskich, przekazywanych drogą ustną.

\subsection{Kolokwializacja}

Nieco inny mechanizm stylizacji można zaobserwować w instrukcji do gry opartej na fabule konkretnej powieści, np. w grze planszowej Achaja, nawiązującej do świata przedstawionego w cyklu powieści Andrzeja Ziemiańskiego. Jest to stylizacja prezentatywna (wskazująca desygnat i opisująca rzeczywistość), z elementami kolokwializacji, w której podstawą staje się styl ogólnopolski, potoczny, mówiony. Wprowadzenie w instrukcji zajmuje kilka stron, zostało wzbogacone o bogatą ikonografię. 
Nadawca zwraca się bezpośrednio do użytkownika w drugiej osobie liczby pojedynczej (wyobraź sobie, posłuchaj, nie dziw się, bądź pewny), stosuje też „my” inkluzywne, wskazujące na opowieść (powróćmy), nie dba o precyzję (gdzieś tam jest...), wypowiada się w sposób sugerujący reakcję na myśli lub słowa odbiorcy (tak, w świecie Achai jest magia). Nawiązanie do powieści następuje poprzez użycie nazw własnych (Achaja, Cesarstwo Luan, Królestwo Arkach, Królestwo Troy, Wielki Las, Chorzy Ludzie, Rada Królestwa, Zakon) oraz względnie wierne, choć wybiórcze zachowywanie realiów opisanych w powieści. Ilustruje to przytoczenie:

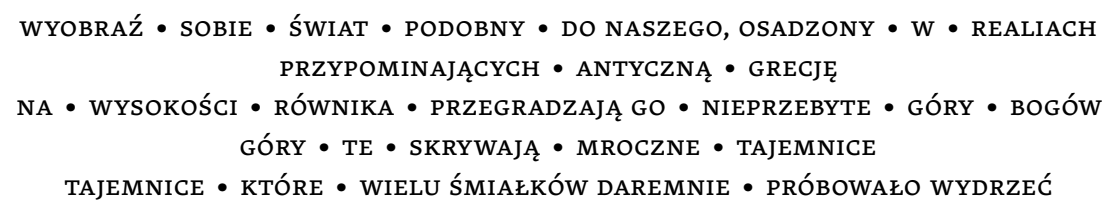

Posłuchaj o Cesarstwie Luan, największym imperium na kontynencie. Jest ono otoczone przez wrogo nastawionych sąsiadów, w tym największego rywala, położonego za wielką pustynią, kolejnego co do wielkości - Królestwo Troy, trawione przez wewnętrzne polityczne konflikty i zewnętrzne starcia militarne.

Gdzieś tam jest też małe Królestwo Arkach, gdzie wojsko składa się wyłącznie z walecznych kobiet, których skąpe skórzane mundury wprawiają obcych wojowników w zakłopotanie. To małe królestwo ma wielkie znaczenie zarówno dla Troy, jak i Luan, gdyż położone jest przy olbrzymim i nieprzebytym leśnym terenie zwanym Wielkim Lasem, za którym znajduje się nadzwyczaj rozwinięty technologicznie kraj Chorych Ludzi. [...] Tak, w świecie Achai jest magia, która potrafi zaburzyć równowagę sił, oraz mistrzowie białej broni - szermierze natchnieni, których - podobnie jak magii - boją się wszyscy. [...] Bądź pewny, że kiedy poczujesz sztylet w plecach, będzie to sprawka któregoś z wielkoksiążęcych rodów. A jak zupełnym przypadkiem spadniesz z konia i złamiesz nogę, która nie będzie się goić i doprowadzi do śmierci - będzie to sprawka Zakonu. I nie zdziw się, kiedy powódź zniszczy całe miasto - w tym ciebie. Rada stoi nad królestwem Troy, ale Zakon stoi nad całym światem. Ich metody są zaiste „światowe”. (18)

Trudno natomiast stwierdzić, czy autor instrukcji próbuje naśladować styl utworu literackiego Ziemiańskiego, czyli zastosować stylizację artystyczną.

\subsection{Stylizacja na język i tekst dawny}

Stylizacje językowe, zwłaszcza archaizacje, częściej zdarzają się w grach opartych na motywach literackich i wątkach historycznych, choć nie stanowi to bezwzględnej reguły (np. w Sigismundus Augustus, 2012, takich 
zabiegów nie ma). W instrukcji do gry Magnum sal (2010) można zaobserwować zapis stylizowany na tekst dawny, kronikarski lub urzędowy.

Roku pańskiego 1368 miłościwie nam panujący Kazimierz Wielki mocą swego królewskiego prawa ustanowił dokument zwany Statutem Żup Krakowskich. Jasno stoi w nim zapisane, iż kto otrzyma z rąk Króla tytuł urzędniczy Żupnika Królewskiego, zarządzać będzie Kopalnią Soli w Wieliczce, Magnum Sal zwaną. Jaśnie Pan żupnikiem swym królewskim tego ze sztygarów mianuje, kto pracą swą dowiedzie, iż fach żupniczy najlepiej opanował i na chwałę Królestwa Polskiego eksploatacyję Żup Krakowskich poprowadzi. (03)

Zwracają tu uwagę formuły grzecznościowe (miłościwie nam panujący, Jaśnie Pan) i leksyka dawna, którą nadawca wyjaśnia kontekstowo: żupa to 'kopalnia, zwłaszcza soli', żupnik w świetle tego tekstu to 'zarządzający kopalnią', statut to 'dokument królewski'. Jedynie leksem eksploatacyja, $\mathrm{z}$ racji użycia dawnej formy, ale rozpoznawanej kontekstowo, nie podlega wyjaśnieniu. Warto podkreślić, że notowany jest dopiero w Słowniku wileńskim (za Żmigrodzkim, 2007-). Także wyrazy zapożyczone z języka niemieckiego - sztygar, kierownik oddziału kopalni, tu 'zarządzający górnikami', i fach 'zawód' - nie otrzymują już eksplikacji, nadawca zakłada ich przynajmniej bierną znajomość. Mają one dawną proweniencję, ale nie są archaizmami. Stylizacja na tekst dawny następuje również dzięki użyciu całych konstrukcji wyrazowych: roku pańskiego, moca prawa ustanowit, stoi $w$ nim zapisane oraz uwidacznia się w budowie zdania, czyli przejawia się upodobaniu do stawianiu orzeczenia w ostatnim członie zdania (stylizacja na składnię łacińską). W instrukcji do gry Na Grunwald (2011) autorzy czynią podobnie:

Jesienią roku pańskiego 1408 jasnym się stało dla miłościwie nam panującego Władysława Jagiełły, że konfrontacja z Wielkim Zakonem Krzyżackim jest nieunikniona. Przygraniczne zatargi i próby rozbicia unii łączącej oba narody Rzeczypospolitej nie pozwalały w to wątpić. Mądry nasz władca rozpoczął więc rychle przygotowania do wojny. Rozesłał w kraj swych oficerów, aby rycerzy do wspólnej sprawy przekonali i do szybkiego pociągnięcia pod chorągwie królewskie gotowi byli. (o8)

Tu również pojawia się etykieta miłościwie nam panujący, dawne frazeologizmy roku pańskiego..., rozesłać $w$ kraj, jasnym się stało, pociagnięcie pod chorągwie, a także charakterystyczna budowa zdania z przestawionym szykiem i czasownikiem na końcu. Szczególny walor mają także nazwy własne, odwołujące się do realiów dawnego świata. W tym tekście nie 
zachodzi stylizowanie na polszczyznę średniowieczną, istotne jest uzyskanie efektu dawnego języka (raczej doby średniopolskiej).

\title{
2.5. Profesjonalizacja
}

Zjawiskiem skrajnie różnym od wcześniej omówionego jest stylizacja na współczesny język techniczny, profesjonalizacja, obecna m.in. w instrukcji do gry Capital (2016), w której uobecnia się w wyrazach i wyrażeniach proces urbanistyczny, architektura (socjalistyczna, międzywojenna, wspótczesna, czasów saskich), zabudowa, tkanka miejska, biurowce, bloki, kamienice. Towarzyszą im jednak ożywiające narrację sformułowania betonowe gmaszyska, kamienice nadgryzione zębem czasu, widać jak na dłoni, co ilustruje przytoczenie:

\begin{abstract}
Warszawa to miasto wyjątkowe. Mówi się, że „przeżyło własną śmierć” - i jest w tym sporo prawdy. Stolica Polski została w większości zniszczona podczas drugiej wojny światowej, a jej odbudowa była wyjątkowym procesem urbanistycznym. Tkanka miejska Warszawy to połączenie wytwornych budynków z czasów saskich, architektury międzywojennej, socjalistycznych bloków i współczesnej zabudowy. Przemierzając ulice warszawskiej dzielnicy Wola, widać tę różnorodność jak na dłoni. Nowoczesne, szklane biurowce bezpośrednio sąsiadują tu z przedwojennymi garażami, a ściany betonowych gmaszysk graniczą z eleganckimi, choć nadgryzionymi zębem czasu kamienicami. Jedni nazywają to przestrzennym bałaganem, inni dopatrują się tu determinacji mieszkańców. Jedni i drudzy mają rację, bo taka właśnie jest Warszawa - może nie najpiękniejsza, ale silna i zdeterminowana. Nic tak dobrze nie oddaje charakteru tego miasta, jak jego zabudowa. (o9)
\end{abstract}

\section{Wnioski}

W instrukcjach do badanych gier planszowych zaistniała także stylizacja na styl publicystyczny, czyli język prasy (Martians..., 2016), kolokwializacja poprzez upodabnianie narracji do listu lub rozmowy (Lord of Hellas, 2018, Azyl, 2018, Nemesis, 2019, Pan Lodowego Ogrodu, 2014, Wiek złodziei, 2016), retoryzacja (stylizacja na przemówienie lub opowieść w języku religijnym, Cthulhu, 2017, i Enclave, 2013), a także na styl urzędowy (ogłoszenie, Kolejka, 2013, Pangea, 2019). Najbardziej niespodziewaną formę przyjęły instrukcje do gier Cthulhu i Enclave, Pangea i This War of Mine. Dziennik (2017). W nich stylizacja objęła inne, liczne fragmenty instrukcji, a choć nadal była raczej fragmentaryczna niż całościowa, to jej znaczenie dla całego tekstu instrukcji było o wiele ważniejsze. 
Podsumowując, wypada podkreślić, że w analizowanych instrukcjach do polskich gier planszowych, zwłaszcza w segmencie wprowadzenia, w około $20 \%$ przypadków pojawia się stylizacja językowa. Niekiedy przyjmuje ona formę archaizacji z elementami dialektyzacji i profesjonalizacji, niekiedy scjentyzacji czy retoryzacji, a także kolokwalizacji oraz stylizacji na język urzędowy. Zauważalne jest również stylizowanie na gatunek (epicki, użytkowy) lub dyskurs (potoczny, religijny). Te zabiegi językowe pozostają w ścisłym związku z funkcją prezentatywną całej instrukcji do gry planszowej, wspierają ją oraz nadają jej silniejszą wymowę impresywną.

Wybór mniej typowej strategii objaśniania fabuły gry wprowadza do produktu element zaskoczenia, dostarcza dodatkowych wrażeń estetycznych, a niekiedy nawet organizuje cały świat gry, co ma miejsce w ostatnich wspomnianych instrukcjach. Ilościowo fragmenty poddane stylizacji językowej nie przeważają, ale dotyczą nie tylko warstwy leksykalnej, lecz i odmiany językowej, gatunku, a nawet dyskursu. Towarzyszy mu zwykle odpowiednia ilustracja. Gdy przyjmie się, że stylizacja posiadająca motywację treściową i językową pełni funkcję potęgowania ekspresji i impresji, słabnie natomiast jej funkcja prezentatywna na rzecz metaprezentatywnej (dotyczącej świata fikcyjnego; Dubisz, 1980), to trzeba uznać, że w gatunku użytkowym instrukcji do gry planszowej dochodzi do zaistnienia sprzeczności (skali paradoksów), a powstały tekst wydaje się gatunkową hybrydą. Odbiega od instrukcji użycia innych produktów ze względu na specyficzny charakter opisywanego produktu, czyli gier planszowych, dla których instrukcja jest paratekstem.

\section{Literatura}

Balbus, S. (1996). Między stylami, wyd. II. Kraków: Towarzystwo Autorów i Wydawców Prac Naukowych „Universitas”.

Borawski, S. (2007), Słownictwo potoczne listów Zygmunta Miłkowskiego do Juliana Eukaszewskiego (1867-1895). Zielona Góra: Oficyna Wydawnicza Uniwersytetu Zielonogórskiego.

Doroszewski, W. (1996), Słownikjęzyka polskiego. Warszawa: Wydawnictwo Naukowe PWN. 
Dubisz, S. (1979). Stylizacja językowa - próba definicji. Prace Filologiczne, 29(1), 191-216.

Kasprzak, K. (2018). Gra planszowa pomocą w czytaniu tekstu literackiego (Henryk Sienkiewicz, W pustyni i w puszczy). Annales Universitatis Paedagogicea Cracoviensis. Studia ad Didactam Literarum Polonarum Linguage Pertinentia, nr 259, 175-184. Online: <http://didactica.up.krakow.pl/ article/view/4968/o>.

Kurowska, K. (2018). Edukacyjny wymiar gier planszowych na podstawie gry Ognisty podmuch. Zeszyty Naukowe SGSP, nr 67, 111-134.

Loewe, I. (2007). Gatunki paratekstowe w komunikacji medialnej. Katowice: Wydawnictwo Uniwersytetu Śląskiego. Online: <https://sbc.org.pl/ Content/50642/gatunki_paratekstowe_w_komunikacji_medialnej. pdf>.

Łączyński, M. (2012). Badanie instrukcji gier z perspektywy twórcy i użytkownika. Homo Ludens, 4(1), 119-133.

Marcjanik, M. (1988). Kreatywna funkcja mowy. Przegląd Humanistyczny, $32(11 / 12), 95-104$.

Mochocka, A. (2015), Polskie gry planszowe oparte na utworach literackich - rekonesans. Biblioteka Postscriptum Polonistycznego, 5(1), 35-47. Online: <http://www.postscriptum.us.edu.pl/pdf/bps2015_5_2.pdf>.

Szczaus, A. (2011). Instrukcja jako forma komunikacji (na przykładzie Informacyi matematycznej Wojciecha Bystrzonowskiego z 1749 roku). W: D. Ostaszewska, J. Przyklęk (red.), Gatunki mowy i ich ewolucja 4: Gatunek a komunikacja społeczna (s. 369-382). Katowice: Wydawnictwo Uniwersytetu Śląskiego.

Szuk-Bernaciak, M. (2010). Instrukcja obsługi jako środek komunikacji typu specjalista-niespecjalista. Lingwistyka Stosowana, 1(2), 171-180. Online: <http://bazhum.muzhp.pl/czasopismo/578/?idno=14624>.

Troszczyńska-Nakonieczna, W. (2007). Strategie instruowania na przykładzie instrukcji obsługi urządzeń technicznych. W: D. Ostaszewska (red.), Gatunki mowy i ich ewolucja 3: Gatunek a odmiany funkcjonalne (s. 184-193). Katowice: Wydawnictwo Uniwersytetu Śląskiego.

Troszczyńska-Nakonieczna, W. (2013). Gwarancja a instrukcja obsługi powiązania dyskursywne. Słowo. Studia Językoznawcze, 4(4), 175-187. Online: <http://ifp.ur.edu.pl/slowo/slowo_4/troszczynska.pdf>. 
Troszczyńska-Nakonieczna, W. (2007). Wzorzec gatunkowy tekstowych instrukcji użytkowania w perspektywie diachronicznej. Stylistyka, 16(1), 501-516.

Uździcka, M. (2017). O nowym pojęciu glosariusza (na materiale literatury fantasy). Rekonesans badawczy. Stylistyka, 26(1), 267-289.

Żmigrodzki, P. (red.). (2007-). Wielki słownik języka polskiego. Online: $<$ https://wsjp.pl>.

Wojtak, M. (2008). Genologia tekstów użytkowych. W: D. Ostaszewska, R. Cudak (red.), Polska genologia lingwistyczna (s. 339-352), Warszawa: PWN.

Wojtak, M. (2001). Pragmatyczne aspekty analiz stylistycznych tekstów użytkowych. W: B. Witosz (red.), Stylistyka a pragmatyka (s. 38-47). Katowice: Wydawnictwo Uniwersytetu Śląskiego.

Wrona, Ł. (2017). Plansza, kości i karty jako forma narracji historycznej: analiza nowoczesnych gier planszowych. Opinie Edukacyjne Polskiej Akademii Umiejętności: prace Komisji PAU do Oceny Podręczników Szkolnych, 15(1), 157-188. Online: <https://www.academia.edu/38236711/ Plansza_ko\%C5\%9Bci_i_karty_jako_forma_narracji_historycznej_-_ analiza_nowoczesnych_gier_planszowych $>$.

Zdunkiewicz-Jedynak, D. (2008). ABC stylistyki. W: E. Wierzbicka, A. Wolański, D. Zdunkiewicz-Jedynak (red.), Podstawy stylistyki i retoryki (s. 39-101). Warszawa: Wydawnictwo Naukowe PWN.

Zielińska, K. (2018). Język i komunikacja w instrukcjach strategicznych gier planszowych. W: A. Drabina-Różewicz, A. Momot (red.), Język i kultura w komunikacji społecznej. Tradycja, teraźniejszość, perspektywy (s.91-103). Wrocław: Stowarzyszenie Młodych Twórców „Kontrast”. Online: <https://depot.ceon.pl/bitstream/ handle/123456789/15587/j\%2Ozyk\%20i\%2okultura\%2Ow\%2okomunikacji\%20spo\%2oecznej.pdf?sequence=1>.

Zielińska K. (2017). Instrukcja gry planszowej - tekst użytkowy czy literacki? Rozprawy Komisji Językowej [Wrocławskie Towarzystwo Naukowe], $43(1)$ 57-66.

Data dostępu do źródeł internetowych wykorzystanych w tekście: 14 września 2019 roku. 


\section{Ludografia}

Arabczyk, G. (2017). Stworze. Underworld Kingdom.

Bachmiński, K., Stachyra, M., Zasowski, M., Mydel, M., Stankiewicz, P. (2005). Labirynt czarnoksiężnika. Kuźnia Gier.

Borsuk, K. (2007). Superfarmer (ed. 3). Granna. Także ed. 2 (1997).

Ginter, T., Madaj, K. (2010-2016). 111. IPN.

Ginter, T., Madaj, K. (2016). 111. IPN.

Grupa LM (2012). Cardio Alarm! Granna.

Gumienny, W., Andruszkiewicz, J. (2014). 1944. Race to the Rhine. Instrukcja. Phalanx.

Huszcza, I., Głowacz, F. (2014). Dice Brewing. Almanach Piwowara. Board \& Dice.

Jagodziński, A. (2019). Pangea. Instrukcja. REDIMP GAMES.

Jagodziński, M. (2017). Pocket Mars. Board \& Dice [gra karciana].

Kalicki, K. (2016). Domek. Rebel.

Kalicki, K. (2017). Domek. Słoneczna 156. Dodatek. Rebel.

Kałuża, A. (2010). K2. Instrukcja. Rebel.

Kałuża, A. (2011). Broad Peak. Rebel.

Kałuża, A. (2012). Jaskinia. Rebel.

Kałuża, A. (2019). Drako. Smok i krasnoludy. Rebel.

Kaznocha, T., Kaźmierski, T. (2013). Wikingowie. Wojownicy Pótnocy. Rebel.

Kijowska, V., Ropka, M. (2015). Twoja kolej. G3.

Kijowska, V., Ropka, M. (2017). Witaj w świecie artefaktów. Portal Games.

Kijowska, V., Ropka, M. (2015). Taste of Poland. Bomba Games [gra karciana].

Krupiński, M., Miłuński, F. (2010). Magnum Sal. Leonardo Games.

Kurek, A. (2011). The Arctic. Alchemicus.pl.

Kurek, A. (2010). Master of Economy. Sinonis.

Kurek, A. (2014). Medieval Battle. The Board Game. Alchemicus.pl.

Kwapiński, A. (2015). Herosi. Instrukcja gry. Lion Games.

Kwapiński, A. (2017). Inbetween. Board \& Dice.

Kwapiński, A. (2018). Lord of Hellas. Instrukcja gry. Phalanx.

Kwapiński, A. (2019). Nemesis. Instrukcja (tłum. M. Żabicka). Rebel.

Kwapiński, A., Sieńko, M. (2012). Sigismundus Augustus. Dei gratia rex Poloniae. Fabryka gier Historycznych. 
Kwapiński, A., Sieńsko, M. (2014). First to Fight. Fabryka Gier Historycznych. Lewandowicz, T. (2012). Amber. Rebel.

Madaj, K. (2015). 7. W obronie Lwowa. Trefl sA.

Madaj, K. (2013). Kolejka. Instrukcja. IPN.

Madaj, K. (2013). Letnisko [Summer Resort]. Gry Leonardo.

Madaj, K. (2016). Planeta Nomino. Trefl sA.

Madaj, K., Ginter, T. (2014), Alarm dla Warszawy. Trefl sA.

Madejski, J. (2018). Niepodległa. Instrukcja do gry. Wersja zaawansowana. IPN. Matusik, K. (2014). Amber Route. Bomba Games.

Matuszczak, K., Pronobis, M. (2009). Arkana miłości. Let’s Play [gra karciana].

Miłuński, F. (2011). Na Grunwald! Rycerze króla Jagiełty. Egmont.

Miłuński, F. (2013). Kosmiczna misja. Egmont.

Miłuński, F. (2016). Capital. Granna.

Miłuński, F. (2017). Batory. Granna.

Miłuński, F. (2011). Mare Balticum. Instrukcja. Gry Leonardo.

Miłuński, F. (2009). Mali Powstańcy. Warszawa 1944. Egmont.

Mirska, M., Sypek, R. (2013). Alternatywy 4. Inte-gra, TVP SA.

Mydel, M., Stachyra, M., Zasowski, M. (2004). Troja. Poprawiona instrukcja i FAQ. Krakowska Grupa Kreatywna.

Mydel, M., Stankiewicz, P., Stachyra, M., Zasowski, M. (2005). Wiochmen Rejser. Instrukcja do gry. Kuźnia Gier [gra karciana].

Mydel, M., Stankiewicz, P. (2013). 7 Ronin. Gra taktyki i wojennej intuicji. Don't Panic Games.

Mydel, M., Stankiewicz, P. (2005-2007). Wiochmen 2. Zasady gry, Kuźnia Gier [gra karciana].

Okliński, G., Wolicki, K. (2016). Martians: A Story of Civilisation. REDIMP GAMES.

Oracz, M. (2013). Neuroshima HEx 3.0. Portal Games.

Oracz, M. (2013). Tezeusz. Mroczna orbita. Portal Games.

Oracz, M., Wiśniewski J. (2018). This War of Mine. Dziennik. Galakta.

Otremba, A. (2012). CLASH: Jihad vs McWorld. Diablos Polacos.

Ozon, M. (2013). Czas Honoru. Operacja Most III. TVP, Phalanx.

Poleszak, M., Szewczyk, M. (2015). Witkacy. Bombagames.

Sosiński, K., Szwelicki, R. (2019). Anno domini 1666. Instrukcja gry. Wargamer Studio. 
Stankiewicz, P. (2007). Pola naftowe. Wydawnictwo Imperium.

Stępień, S. (2016). Wiek złodziei. Zasady gry. Galakta.

Szopa, M. (2012). Orty i rakiety. Eagles \& Missiles. Zasady gry. Mars Games.

Tomczyk, M. (2005). Wyprawa. Towarzyska gra fantasy. Krakowska Grupa Kreatywna.

Trzewiczek, I. (2014). Osadnicy. Narodziny Imperium. Portal Games.

Trzewiczek, I. (2014). Wiedźmin. Gra przygodowa. Podręcznik zasad. Fantasy Flight Games.

Trzewiczek, I. (2015). Stronghold (ed. 2). Portal Games.

Trzewiczek, I. (2016). 51. stan. Portal Games.

Trzewiczek, I. (2017). Pierwsi Marsjanie. Przygody na czerwonej planecie. Instrukcja. Portal Games.

Trzewiczek, I. (2018). Detektyw. Kryminalna gra planszowa. Portal Games. Trzewiczek, I. (2019). Prêt a Porter. Portal Games.

Trzewiczek, I. (2012). Robinson Crusoe. Przygoda na przeklętej wyspie. Edycja Gra roku. Instrukcja. Portal Games.

Trzewiczek, I. (2014). Wiedźmin. Gra przygodowa. Skrócona instrukcja. Fantasy Flight Games.

Trzewiczek, I. (2010). Zombiaki II. Atak na Moskwę. Portal Games [gra karciana].

Walczewska-Bińczyk, I., Walczewski, O., Kwapiński, A. (2012). W Zakładzie - Lubelski Lipiec '8o. Fabryka Gier Historycznych.

Wełnicki, M. (2011). Zagłada Atlantydy. Galakta.

Wełnicki, M. (2014). Slavika. Równonoc. Equinox. Rebel.

Wojtkowiak, P. (2017). Azyl. Zagrożone gatunki. CUBE FACTORY OF IDEAS.

Wolicki, K. (2013). Enclave. Zakon krańca świata. st Games Spółka z o.o.

Wolicki, K. (2014). Pan Lodowego Ogrodu (ed. 2). REDimP GAMES.

Wolicki, K. (2015). Achaja. REDIMP GAMES.

Wolicki, K. (2018). Atlantis. Island of Gods. REDIMP GAMES.

Wolicki, K. (2017). Cthulhu. Rise of the Cults. REDIMP GAMES.

Woźniak, Ł. (2013). Pirackie skarby. Egmont.

Zalewski, J. (2015). Andromeda. Galakta.

Zalewski, J. (2015). cvlizacje. Granna.

Wszystkie gry wskazane w ludografii zostały wydane w Polsce. 
dr hab. Iwona Pałucka-Czerniak - prof. UZ, językoznawca, pracuje w Instytucie Filologii Polskiej, Uniwersytet Zielonogórski, Zielona Góra

\title{
Stylizacja językowa w instrukcjach do polskich gier planszowych
}

\begin{abstract}
Abstrakt: Artykut omawia zjawisko stylizacji w gatunku instrukcji, w jej pododmianie instrukcji do gry planszowej. Uznaje się, że w tekście instrukcji dochodzi do kreacji językowej, wprowadzającej gracza w swoisty świat gry. Umożliwia ona dalsze tworzenie znaczeń w procesie rozgrywki, włącza użytkowników w oparty na kulturze interaktywny system znaków. Stylizacja występuje w około $20 \%$ badanych współczesnych polskich tekstów. Wybór mniej typowej strategii objaśniania fabuły gry wprowadza do produktu element zaskoczenia, dostarcza dodatkowych wrażeń estetycznych, a niekiedy nawet organizuje cały świat gry. Ilościowo fragmenty poddane stylizacji językowej nie przeważają. Zabiegi te występują jednak w ramie tekstowej oraz dotyczą nie tylko warstwy leksykalnej, ale i odmiany językowej, gatunku, a nawet dyskursu.
\end{abstract}

Stowa kluczowe: stylizacja, instrukcja, gatunek, pragmalingwistyka 